\title{
Update of reference values for IgG antibodies against typical antigens of hypersensitivity pneumonitis
}

\section{Data of a German multicentre study}

\author{
Monika Raulf · Marcus Joest • Ingrid Sander · Frank Hoffmeyer · Dennis Nowak · Uta Ochmann · \\ Alexandra Preisser · Jens Schreiber · Joachim Sennekamp · Dirk Koschel
}

Received: 11 January 2019 / Accepted: 17 April 2019 / Published online: 27 May 2019

(c) The Author(s) 2019

\begin{abstract}
Background Specific (s)IgG antibodies against environmental and occupational antigens, especially from bacteria, moulds, yeasts, birds and chemicals play an important role for hypersensitivity pneumonitis (HP). An increased serum level of sIgG is one criterion in the diagnostic procedure of HP and crucial for the detection of the triggering antigen for successful avoidance of further exposure. In contrast to specific IgE, sIgG
\end{abstract}

Prof. Dr. M. Raulf $(\bowtie) \cdot$ I. Sander $\cdot$ F. Hoffmeyer Institute for Prevention and Occupational Medicine of the German Social Accident Insurance, Ruhr University Bochum (IPA), Bürkle-de-la-Camp-Platz 1, 44789 Bochum, Germany raulf@ipa-dguv.de

M. Joest · J. Sennekamp

Malteser Lung- und Allergy Centre Bonn, Bonn, Germany

D. Nowak · U. Ochmann

Institute and Outpatient Clinic for Occupational, Social and Environmental Medicine, University Hospital (LMU), Comprehensive Pneumology Center Munich (CPC-M), Member DZL, German Center for Lung Research, Munich, Germany

\section{A. Preisser}

Institute for Occupational and Maritime Medicine, University Medical Center Hamburg-Eppendorf, Hamburg, Germany

\section{J. Schreiber}

University Clinic of Pneumology, Magdeburg, Germany

\section{Koschel}

Department of Pulmonary Diseases, Fachkrankenhaus Coswig, Centre for Pulmonary Diseases and Thoracic Surgery, Coswig, Germany

Division of Pulmonology, Medical Department I, University Hospital Carl Gustav Carus, Technische Universität Dresden, Dresden, Germany concentrations in healthy individuals vary greatly depending on the antigen, which makes it difficult to differentiate from patients with HP. The aim of this study is to update or establish sIgG-reference values for important HP antigens in a healthy blood donor group.

Methods Therefore a study including six clinical centres in Germany was conducted to collect sera from 121 subjects without any signs of HP and without obvious exposure to potential HP antigens. Specific IgG to 32 typical HP antigens were quantified by ImmunoCAP (ThermoFisher Scientific; Phadia, Uppsala, Sweden). For validation selected measurements were repeated, total IgG was determined, sera were tested for unspecific binding with the human serum albumin ImmunoCAP Ro401, and influence of potential confounders was analysed. Statistical distribution of the antigen-specific IgG values was evaluated and the nonparametric method of percentile calculation was applied.

Results The levels of IgG antibodies to the different antigens varied considerably in the study group from $<0.02$ to $726 \mathrm{mg}_{\mathrm{A}} / \mathrm{L}$. Low sIgG levels were found against the chemicals and the highest levels to fungal antigens, especially to Aspergillus fumigatus and Botrytis cinerea. For three isocyanates, three acid anhydrides, Trichosporon pullulans and Acremonium kiliense reference values were proposed for the first time. For several avian antigens, moulds, and bacteria pre-existing reference values nearly could be confirmed without significant deviations, but already the $90 \%$ quantile for sIgG against Penicillium chrysogenum, Aspergillus fumigatus and pigeon antigen (Ge91) clearly exceeded the pre-existing values. In contrast, the $97.5 \%$ quantile value for Candida albicans was nearly half of the pre-existing cut-off value. 
Discussion In most cases specific IgG values were not significantly influenced by smoking and gender and most of them were unaffected by age. For implementation of these sIgG reference values into the routine diagnosis of HP, we provide an online available calculator to rank measured sIgG concentrations to the 32 different ImmunoCAP antigens.

Keywords Antigen specific IgG · Diagnosis · Hypersensitivity pneumonitis - Reference values . Extrinsic allergic alveolitis

Abbreviations

CV Coefficient of variation

EAA Extrinsic allergic alveolitis

FEIA Fluorescent enzyme immunoassay

HSA Human serum albumin

HP Hypersensitivity pneumonitis

MBP Maltose-binding protein

$\mathrm{mg}_{\mathrm{A}} / \mathrm{L} \quad$ Milligrams of antigen-specific IgG per liter

SD Standard deviation

(s)IgG Specific immunglobulin G

\section{Introduction}

Hypersensitivity pneumonitis (HP), also known as extrinsic allergic alveolitis (EAA), is a respiratory syndrome involving the lung parenchyma and specifically the alveoli, terminal bronchioles, and alveolar interstitium, due to a delayed allergic reaction [1]. In several cases HP is associated with a repeated and prolonged inhalation of compounds with immunogenic properties and is accompanied by systemic manifestations (e.g. fever and weight loss). Clinical presentation and disease progression can be extremely variable, depending on the nature of the causal agent, exposure duration, and intensity, as well as individual host factors [1]. The spectra of typical HP-inducing antigens are commonly classified into five broad categories: animal (especially avian antigens) proteins, plant proteins, fungi/yeasts, bacteria/mycobacteria and lowmolecular chemicals [2]. Continuous contact with the antigen can lead to permanent lung damage [3]. Although agents capable of inducing HP are found in a number of settings, including the workplace, home and recreational environments, HP is an orphan disease and only a minority of individuals exposed to potential HP-inducing antigens develop the disease [4]. However, many exposed individuals develop an antigen-specific immune response apparent as presence of antigen-specific (s)IgG antibodies in serum and an increased number of lymphocytes in the lung, but they never develop HP. Although antigen-sIgG antibodies are only a marker of exposure, in the appropriate clinical setting, an elevated sIgG concentration supports the diagnosis of HP and helps to identify the triggering antigen. In contrast, the absence of elevated sIgG antibody levels does not rule out HP, primarily because only a limited number of HP antigens are commercially available for routine testing. Despite these limitations, determination of sIgG antibodies is important for the diagnosis and prognosis of HP and the result of quantitative determination of antigen SIgG is one criterion of the diagnostic algorithms of HP $[5,6]$. For the determination of SIgG, several qualitative techniques like precipitation, agglutination, immunoblots or quantitative tests like enzyme-linked immunoassays are used. Comparison of data obtained with different methods is almost impossible based on lack of standardization of for example the different antigen sources and techniques. Additionally, the interpretation of data is rendered more difficult by the fact that no common agreement for cut-off values exists, i.e. what is the "normal range" in healthy subjects and what are "pathologic" values in patients suffering from HP? In contrast to specific IgE, the cut-off values for different IgG antigens cannot be considered as a uniform value and vary in a broad range depending on the specific antigen. Therefore, the aim of our study was to establish sIgG reference values for not yet evaluated HP antigens and to validate pre-existing values in a healthy donor blood group. We collected sera from healthy volunteers without any signs of HP and without obvious exposure to potential HP antigens in six clinical centres in Germany. For the determination of sIgG we used the frequently applied technique of IgG-ImmunoCAP method providing absolute values.

\section{Materials and methods}

\section{Study design and sera collection}

Six clinical centres in Germany (Department of Pulmonary Diseases, Fachkrankenhaus Coswig, Centre for Pulmonary Diseases and Thoracic Surgery, Coswig; Institute and Outpatient Clinic for Occupational, Social and Environmental Medicine, University Hospital [LMU], Munich; Institute for Occupational and Maritime Medicine, University Medical Center HamburgEppendorf [UKE]; Institute for Prevention and Occupational Medicine of the German Social Accident Insurance, Institute of the Ruhr University Bochum [IPA]; Malteser Lung und Allergy Centre Bonn; University Clinic of Pneumology, Magdeburg) participated in the study. The study design and the protocol were reviewed and approved by the ethical committee of the Technische Universität Dresden (EK 195052014) in accordance with the Declaration of Helsinki and ethical approval was obtained from the local ethic committee of each centre. In total 121 sera were collected from subjects without any history and clinical signs of HP and without obvious exposure to potential HP antigens or other pulmonary diseases. In addition, subjects with general condition 4 according to the World Health Organisation, with a history of clinical signs of interstitial lung disease, rheumatological and/or immunological diseases and with obstructive 
Table 1 Antigens used for specific IgG determination

\begin{tabular}{|c|c|}
\hline Class of antigens & Specific antigens \\
\hline Mould/Fungi & $\begin{array}{l}\text { Penicillium chrysogenum (m1), Cladosporium herbarum (m2), Aspergillus fumigatus (m3), Mucor racemosus (m4), Candida albicans (m5), } \\
\text { Alternaria alternata (m6), Botrytis cinerea (m7), Fusarium proliferatum (m9), Rhizopus nigricans (m11), Aureobasidium pullulans (m12), } \\
\text { Trichoderma viride (m15), Stachybotris atra (Gm24), Acremonium (m202), Trichosporon pullulans (m203), Mould mix (Gmx6 including } \\
\mathrm{m} 1, \mathrm{~m} 2, \mathrm{~m} 4, \mathrm{~m} 6)\end{array}$ \\
\hline Bacteria & Saccharopolyspora rectivirgula (Gm22), Thermoactinomyces vulgaris (Gm23), Thermophilic bacteria mixture (Gmx7 including Gm22, Gm23) \\
\hline Animal proteins & $\begin{array}{l}\text { Budgerigar serum protein, feathers and droppings (Ge90), Pigeon serum proteins, feathers and droppings (Ge91), Parrot serum proteins, } \\
\text { feathers and droppings (Ge92), Pigeon serum proteins (Ge93), Goose feathers (e70), Chicken feathers (e85), Duck feathers (e86), Canary } \\
\text { feathers (e201) }\end{array}$ \\
\hline Chemicals & $\begin{array}{l}\text { Isocyanate- toluene diisocyanate (TDI) (k75), Isocyanate- diphenylmethane diisocyanate (MDI) (k76), Isocyanate- hexamethylene diiso- } \\
\text { cyanate (HDI) (k77), Phthalic acid (k79), Trimellitic acid (k86), Methyltetrahydrophthalic anhydride (k211) }\end{array}$ \\
\hline
\end{tabular}

Table 2 Characteristics of the study group $(n=121)$

\begin{tabular}{|c|c|c|}
\hline \multicolumn{3}{|l|}{ Gender } \\
\hline Male (\%) & 53 & $(44 \%)$ \\
\hline Female (\%) & 68 & $(56 \%)$ \\
\hline \multicolumn{3}{|l|}{ Age (years) } \\
\hline Median (range) & 43 & $(21-83)$ \\
\hline \multicolumn{3}{|l|}{ Number } \\
\hline$<30$ years & 28 & $(23 \%)$ \\
\hline $30-45$ years & 44 & $(37 \%)$ \\
\hline $45-60$ years & 28 & $(23 \%)$ \\
\hline$>60$ years & 21 & $(17 \%)$ \\
\hline \multicolumn{3}{|l|}{ Smoking } \\
\hline Never smoker (\%) & 75 & $(62 \%)$ \\
\hline Former smoker (\%) & 28 & $(23 \%)$ \\
\hline Current smoker (\%) & 18 & $(15 \%)$ \\
\hline
\end{tabular}

pulmonary diseases and/or emphysema were excluded. The intake of drugs with immunomodulating effects excluded participation and most of the volunteers did not take any medication at the time of the blood collection. A questionnaire concerning exposure, respiratory symptoms and smoking habits was completed and a written consent was obtained from all blood donors in each centre. In most of the participating centre employees volunteered to participate in the study and sera were collected from assistant staff (laboratory, ambulance), scientific staff (medical doctors, chemists, biologists). Additionally in one clinic patients who came to the sleep laboratory for examination participated in the study. In another centre, employees in warehouse logistics, who received occupational medical check-ups and/or aptitude examinations, were also included in the study (13 out of 121). The participants came both from the intercity areas as well as from the surroundings of the study centres. No study participant was employed in the agriculture field and none was exposed to isocyanates. All study participants stated that there was no exposure and none in recent years to avian and mould.

\section{Determination of total and specific lgG}

Specific IgG to 32 typical HP antigens and antigen mixtures, respectively (Table 1) were centrally quantified in one facility (IPA) using ImmunoCAP specific IgG and the ImmunoCAP 250 system (ThermoFisher Scientific, Phadia AB, Uppsala, Sweden) according to the manufacturer's instructions. This procedure uses a FEIA (fluorescent enzyme immunoassay) methodology, and for the sIgG antibody determination the sera were diluted 1:100 with the specific IgA/IgG sample diluent. The calibration for antigen-specific IgG analysis follows the same principle as the heterologous calibration that is used for allergen-specific IgE analysis. Results are expressed in milligrams of antigenspecific IgG per liter $\left(\mathrm{mg}_{\mathrm{A}} / \mathrm{L}\right)$. Unspecific IgG binding was measured using the human serum albumin (HSA) ImmunoCAP Ro401. The manufacturer stated $2 \mathrm{mg}_{\mathrm{A}} / \mathrm{L}$ as limit of quantification, but for a complete assessment of the SIgG concentrations the measuring range between 200 and 0.02 (detection limit) $\mathrm{mg}_{\mathrm{A}} / \mathrm{L}$ was used. Sera with sIgG concentrations above 200 $\mathrm{mg}_{\mathrm{A}} / \mathrm{L}$ were reanalysed after dilution. Results of selected measurements were repeated. Comparison of the calibrator counts, curve data, and quality control calculated values showed that the runs were acceptable. Total IgG was determined with the turbimetric method using the UniCel DXC 800 and SYNCHRON as IgG reagent (Beckman Coulter, Brea, CA, USA) according to the manufacturer's recommendations. The reference range was between 7000 and $16,000 \mathrm{mg} / \mathrm{L}$.

\section{Statistical methods}

IgG results were expressed as range minimum and maximum, median, $75 \%, 90 \%, 95 \%$ and the $97.5 \%$ quantile. Quantiles were calculated with Microsoft Excel 2010 with the function Quantil.exkl. Coefficient of variation (CV) was used to describe the repeatability and calculated with Microsoft Excel 2010 (Microsoft, Redmond, WA, USA). The Kolmogorov-Smirnov normality test was used to assess the distribution of the values and selected histograms were visualized with Graph Pad Prism 5.04 for Windows (GraphPad Software, Inc., La Jolla, CA, USA). For correlations between all specific and total IgG values, the Spearman rank 
Table 3 Specific IgG values against fungi

\begin{tabular}{|c|c|c|c|c|c|c|c|c|}
\hline Antigen & $\begin{array}{l}\text { Range } \\
\text { (min-max) } \\
{\left[\mathrm{mg}_{A} / \mathrm{L}\right]}\end{array}$ & $\begin{array}{l}\text { Values } \\
<2 \mathrm{mg}_{\mathrm{A}} / \mathrm{L} \\
{[n]}\end{array}$ & $\begin{array}{l}\text { Median } \\
{\left[\mathrm{mg}_{\mathrm{A}} / \mathrm{L}\right]}\end{array}$ & $\begin{array}{l}75 \% \text { Quantile } \\
{\left[\mathrm{mg}_{\mathrm{A}} / \mathrm{L}\right]}\end{array}$ & $\begin{array}{l}90 \% \text { Quantile } \\
{\left[\mathrm{mg}_{\mathrm{A}} / \mathrm{L}\right]}\end{array}$ & $\begin{array}{l}95 \% \text { Quantile } \\
{\left[\mathrm{mg}_{\mathrm{A}} / \mathrm{L}\right]}\end{array}$ & $\begin{array}{l}97.5 \% \text { Quantile } \\
{\left[\mathrm{mg}_{\mathrm{A}} / \mathrm{L}\right]}\end{array}$ & $\begin{array}{l}\text { ThermoFisher } \\
\text { Cut-off } \\
{\left[\mathrm{mg}_{\mathrm{A}} / \mathrm{L}\right]}\end{array}$ \\
\hline Mould mix (Gmx6) & $1.2-41.0$ & 3 & 8.3 & 13.1 & 21.5 & 26.8 & 32.0 & 30 \\
\hline Penicillium chrysogenum (m1) & $1.8-143.4$ & 1 & 17.0 & 26.0 & 47.1 & 71.6 & 85.6 & 27 \\
\hline Cladosporium herbarum (m2) & $2.2-64.5$ & 0 & 11.3 & 20.3 & 30.4 & 38.2 & 49.3 & $37^{a}$ \\
\hline Aspergillus fumigatus (m3) & $2.6-726.1$ & 0 & 21.3 & 38.8 & 78.0 & 97.2 & 140.6 & $39^{a}$ \\
\hline Mucor racemosus (m4) & $0.7-12.0$ & 34 & 2.6 & 4.0 & 5.4 & 6.5 & 9.0 & 10 \\
\hline Candida albicans (m5) & $2.3-111.7$ & 0 & 26.1 & 43.7 & 57.2 & 69.5 & 77.5 & $150^{\mathrm{a}}$ \\
\hline Alternaria alternata (m6) & $0.3-15.0$ & 37 & 2.9 & 4.4 & 6.9 & 9.9 & 12.2 & $12^{a}$ \\
\hline Botrytis cinerea $(\mathrm{m} 7)$ & $0.3-572.3$ & 2 & 25.8 & 47.0 & 98.1 & 141.1 & 171.5 & 115 \\
\hline Fusarium proliferatum (m9) & $0.9-92.2$ & 11 & 8.9 & 23.7 & 37.4 & 46.5 & 54.6 & 46 \\
\hline Rhizopus nigricans (m11) & $0.2-13.8$ & 68 & 1.8 & 3.0 & 5.0 & 6.4 & 7.6 & 8 \\
\hline Aureobasidium pullulans (m12) & $0.2-26.4$ & 38 & 3.1 & 5.1 & 8.4 & 12.3 & 15.0 & 22 \\
\hline Trichoderma viride (m15) & $0.3-31.8$ & 43 & 2.7 & 4.8 & 9.8 & 12.3 & 21.3 & 17 \\
\hline Stachybotris atra (Gm24) & $0.5-10.9$ & 53 & 2.3 & 4.1 & 6.3 & 8.0 & 8.3 & 11 \\
\hline Acremonium kiliense (m202) & $0.7-39.3$ & 11 & 5.4 & 9.1 & 15.2 & 18.8 & 22.6 & l \\
\hline Trichosporon pullulans (m203) & $0.2-11.3$ & 34 & 2.7 & 4.6 & 6.9 & 9.9 & 11.1 & l \\
\hline
\end{tabular}

Table 4 Specific IgG values against bacteria

\begin{tabular}{|c|c|c|c|c|c|c|c|c|}
\hline Antigen & $\begin{array}{l}\text { Range } \\
\text { (min-max) } \\
{[\mathrm{mgA} / \mathrm{L}]}\end{array}$ & $\begin{array}{l}\text { Values }<2 \\
\mathrm{mg}_{\mathrm{A}} / \mathrm{L}[n]\end{array}$ & $\begin{array}{l}\text { Median } \\
{\left[\mathrm{mg}_{\mathrm{A}} / \mathrm{L}\right]}\end{array}$ & $\begin{array}{l}75 \% \text { Quantile } \\
{\left[\mathrm{mg}_{\mathrm{A}} / \mathrm{L}\right]}\end{array}$ & $\begin{array}{l}90 \% \text { Quantile } \\
{\left[\mathrm{mg}_{A} / \mathrm{L}\right]}\end{array}$ & $\begin{array}{l}\text { 95\% Quantile } \\
{\left[\mathrm{mg}_{\mathrm{A}} / \mathrm{L}\right]}\end{array}$ & $\begin{array}{l}\text { 97.5\% Quantile } \\
{\left[\mathrm{mg}_{\mathrm{A}} / \mathrm{L}\right]}\end{array}$ & $\begin{array}{l}\text { ThermoFisher } \\
\text { Cut-off } \\
{\left[\mathrm{mg}_{\mathrm{A}} / \mathrm{L}\right]}\end{array}$ \\
\hline $\begin{array}{l}\text { Thermophilic bacteria mixture } \\
(\mathrm{Gmx} 7)\end{array}$ & $0.8-18.2$ & 17 & 5.5 & 7.4 & 10.7 & 12.7 & 14.6 & 20 \\
\hline $\begin{array}{l}\text { Saccharopolyspora rectivirgula } \\
\text { (Gm22) }\end{array}$ & $0.2-14.2$ & 68 & 1.7 & 2.7 & 4.2 & 5.2 & 6.1 & 10 \\
\hline $\begin{array}{l}\text { Thermoactinomyces vulgaris } \\
\text { (Gm23) }\end{array}$ & $0.8-29.8$ & 12 & 6.9 & 11.4 & 16.4 & 21.5 & 24.7 & 29 \\
\hline
\end{tabular}

Table 5 Specific IgG values against avian proteins

\begin{tabular}{|c|c|c|c|c|c|c|c|c|}
\hline Antigen & $\begin{array}{l}\text { Range } \\
\text { (min-max) } \\
{\left[\mathrm{mg}_{\mathrm{A}} / \mathrm{L}\right]}\end{array}$ & $\begin{array}{l}\text { Values }<2 \\
\mathrm{mg}_{\mathrm{A}} / \mathrm{L}[n]\end{array}$ & $\begin{array}{l}\text { Median } \\
{\left[\mathrm{mg}_{\mathrm{A}} / \mathrm{L}\right]}\end{array}$ & $\begin{array}{l}75 \% \text { Quantile } \\
{\left[\mathrm{mg}_{\mathrm{A}} / \mathrm{L}\right]}\end{array}$ & $\begin{array}{l}90 \% \text { Quantile } \\
{\left[\mathrm{mg}_{\mathrm{A}} / \mathrm{L}\right]}\end{array}$ & $\begin{array}{l}\text { 95\% Quantile } \\
{\left[\mathrm{mg}_{\mathrm{A}} / \mathrm{L}\right]}\end{array}$ & $\begin{array}{l}\text { 97.5\% Quantile } \\
{\left[\mathrm{mg}_{\mathrm{A}} / \mathrm{L}\right]}\end{array}$ & $\begin{array}{l}\text { ThermoFisher } \\
\text { Cut-off } \\
{\left[\mathrm{mg}_{A} / \mathrm{L}\right]}\end{array}$ \\
\hline $\begin{array}{l}\text { Budgerigar serum proteins } \\
\text { feathers and droppings (Ge90) }\end{array}$ & $0.7-18.0$ & 22 & 3.1 & 4.4 & 7.6 & 10.0 & 11.3 & 11 \\
\hline $\begin{array}{l}\text { Pigeon serum proteins, feathers } \\
\text { and droppings (Ge91) }\end{array}$ & $2.4-42.9$ & 0 & 9.3 & 14.6 & 19.8 & 28.3 & 35.6 & 10 \\
\hline $\begin{array}{l}\text { Parrot serum proteins, feathers } \\
\text { and droppings (Ge92) }\end{array}$ & $0.7-32.4$ & 5 & 4.5 & 6.6 & 9.9 & 13.6 & 19.7 & 10 \\
\hline Pigeon serum proteins (Ge93) & $0.2-7.8$ & 107 & 0.8 & 1.4 & 2.1 & 2.7 & 3.6 & 10 \\
\hline Goose feathers (e70) & $1.6-18.8$ & 5 & 4.9 & 6.6 & 9.4 & 11.5 & 14.9 & 10 \\
\hline Chicken feathers (e85) & $1.6-26.8$ & 2 & 5.6 & 6.8 & 9.2 & 12.6 & 19.0 & 14 \\
\hline Duck feathers (e86) & $1.0-15.2$ & 7 & 4.0 & 5.5 & 7.5 & 9.4 & 13.8 & 10 \\
\hline Canary feathers (e201) & $0.5-14.2$ & 60 & 2.0 & 2.9 & 4.2 & 5.5 & 7.3 & 11 \\
\hline
\end{tabular}

correlation method was used because data were not normally distributed. Data were analysed with Graph Pad Prism 5.04.

\section{Results \\ Determination of antigen-specific lgG concentrations}

Sera were collected from 121 healthy subjects and the characteristics of the study group are presented in Table 2: a total of $56 \%$ of the blood donors were females, the median age of all subjects was 43 years (range 
Table 6 Specific IgG values against chemicals

\begin{tabular}{|c|c|c|c|c|c|c|c|c|}
\hline Antigen & $\begin{array}{l}\text { Range } \\
\text { (min-max) }\end{array}$ & $\begin{array}{l}\text { Values }<2 \\
\mathrm{mg}_{\mathrm{A}} / \mathrm{L}[n]\end{array}$ & $\begin{array}{l}\text { Median } \\
{\left[\mathrm{mg}_{\mathrm{A}} / \mathrm{L}\right]}\end{array}$ & $\begin{array}{l}75 \% \text { Quantile } \\
{\left[\mathrm{mg}_{\mathrm{A}} / \mathrm{L}\right]}\end{array}$ & $\begin{array}{l}90 \% \text { Quantile } \\
{[\mathrm{mg} / \mathrm{L}]}\end{array}$ & $\begin{array}{l}\text { 95\% Quantile } \\
{[\mathrm{mg} / \mathrm{L}]}\end{array}$ & $\begin{array}{l}97.5 \% \text { Quantile } \\
{\left[\mathrm{mg}_{A} / \mathrm{L}\right]}\end{array}$ & $\begin{array}{l}\text { ThermoFisher } \\
\text { Cut-off } \\
{\left[\mathrm{mg}_{A} / \mathrm{L}\right]}\end{array}$ \\
\hline Isocyanate-TDI (k75) & $<0.02-6.8$ & 112 & 1.0 & 1.3 & 1.9 & 2.4 & 3.4 & I \\
\hline Isocyanate-MDI (k76) & $0.03-5.5$ & 113 & 0.8 & 1.0 & 1.5 & 2.1 & 2.4 & I \\
\hline Isocyanate-HDI (k77) & $<0.02-5.1$ & 118 & 0.5 & 0.7 & 1.3 & 1.7 & 2.2 & I \\
\hline Phthalic acid (k79) & $0.2-8.6$ & 92 & 1.3 & 1.9 & 3.4 & 3.7 & 5.5 & 1 \\
\hline Trimellitic acid (k86) & $0.04-8.8$ & 101 & 0.9 & 1.5 & 2.6 & 3.4 & 3.9 & I \\
\hline $\begin{array}{l}\text { Methyltetrahydrophthalic } \\
\text { anhydride (k211) }\end{array}$ & $<0.02-6.3$ & 113 & 0.8 & 1.0 & 1.9 & 2.5 & 3.1 & I \\
\hline
\end{tabular}

21-83 years), $62 \%$ of the subjects were never smokers and only $15 \%$ were current smokers.

All 121 sera were tested for sIgG binding to 32 antigens (two of them are mixtures, mould mixture [Gmx6] and thermophilic bacteria mixture [Gmx7]) and HSA (Ro401) and displayed individual binding profiles. In 2583 out of 3872 sIgG determinations (121 sera tested with 32 antigens) IgG antibodies were detected with concentrations above $2 \mathrm{mg}_{\mathrm{A}} / \mathrm{L}(66.7 \%$; Tables 3, 4, 5 and 6). Based on the significant differences between raw data and normal distribution (tested with the Kolomogorov-Smirnov test; Figs. 1, 2 and 3), non-parametric methods were used and the results are described as median and quantiles.

The levels of IgG antibodies to the different antigens varied considerably in the study group from $<0.02$ to $726 \mathrm{mg}_{\mathrm{A}} / \mathrm{L}$ (Tables $3,4,5$ and 6). Low sIgG levels were found against the chemicals (median values between 0.5 and $1.3 \mathrm{mg}_{\mathrm{A}} / \mathrm{L}$; Table 6) and the highest levels to fungal antigens, especially to Aspergillus fumigatus and Botrytis cinerea (Table 3). In all sera the specific IgG concentrations against Aspergillus fumigatus, Cladosporium herbarum and Candida albicans were $>2 \mathrm{mg}_{\mathrm{A}} / \mathrm{L}$, whereas 68 out of 121 (56\%) sIgG values against Rhizopus nigricans were $<2 \mathrm{mg}_{\mathrm{A}} / \mathrm{L}$ (Table 3). The concentrations of IgG to Mucor racemosus, Alternaria alternata, Rhizopus nigricans, Stachybotris atra, and Trichosporon pullulans were generally lower than for the other fungal antigens $\left(97.5 \%\right.$ quantile $\left.<15 \mathrm{mg}_{\mathrm{A}} / \mathrm{L}\right)$. For several fungal antigens the $97.5 \%$ quantile was in the same range as the pre-existing cut-off values (suggested by ThermoFisher). The 97.5\% quantile for sIgG against Penicillium chrysogenum (85.6 $\left.\mathrm{mg}_{\mathrm{A}} / \mathrm{L}\right)$, Aspergillus fumigatus $\left(140.6 \mathrm{mg}_{\mathrm{A}} / \mathrm{L}\right)$ and Botrytis cinerea (171.5 $\mathrm{mg}_{\mathrm{A}} / \mathrm{L}$ ) clearly exceeded the pre-existing suggested cut-off values (more than 3 -fold higher values). In contrast, the $97.5 \%$ quantile for sIgG against Candida albicans $\left(77.5 \mathrm{mg}_{\mathrm{A}} / \mathrm{L}\right)$ was nearly half of the pre-existing value (Table 3). For Acremonium kiliense and Trichosporon pullulans no cut-off values suggested by the company existed.

The levels of IgG antibodies to bacteria antigens varied from 0.2 to $29.8 \mathrm{mg}_{\mathrm{A}} / \mathrm{L}$ (Table 4). Most of the low values were found against Saccharopolyspora rec- tivirgula, in detail $56 \%$ of the sera had concentrations $<2 \mathrm{mg}_{\mathrm{A}} / \mathrm{L}$ against this antigen. The $97.5 \%$ quantile for the thermophilic bacteria mixture (including both Gm22 and Gm23) and for the two bacteria was lower than the pre-existing cut-off value.

The levels of IgG antibodies to eight animal antigens ranged from 0.2 to $42.9 \mathrm{mg}_{\mathrm{A}} / \mathrm{L}$ (Table 5). In only $12 \%$ of the sera sIgG concentrations against pigeon serum proteins (Ge93) were $>2 \mathrm{mg}_{\mathrm{A}} / \mathrm{L}$ and the maximum value was $7.8 \mathrm{mg}_{\mathrm{A}} / \mathrm{L}$. Therefore the $97.5 \%$ quantile for sIgG against pigeon serum proteins $\left(3.6 \mathrm{mg}_{\mathrm{A}} / \mathrm{L}\right)$ was more than half of the pre-existing cut-off value. In contrast, in all sera the sIgG concentrations to Ge91 (pigeon serum proteins, feather and droppings) were $>2 \mathrm{mg}_{\mathrm{A}} / \mathrm{L}$ and the $97.5 \%$ quantile $\left(35.6 \mathrm{mg}_{\mathrm{A}} / \mathrm{L}\right)$ was 3.5-fold higher than the suggested pre-existing cut-off value. Specific IgG concentrations against parrot serum proteins, feathers and droppings (Ge92) reached a maximum value of $32.4 \mathrm{mg}_{\mathrm{A}} / \mathrm{L}$ and the $97.5 \%$ quantile was twice as high as the suggested cut-off value. Low sIgG values found against canary feather antigen (e201) with $49 \%$ of the values $<2 \mathrm{mg}_{\mathrm{A}} / \mathrm{L}$ and a $97.5 \%$ quantile of $7.3 \mathrm{mg}_{\mathrm{A}} / \mathrm{L}$. For the other animal antigens the $97.5 \%$ quantile was in the same range than the pre-existing cut-off values (suggested by ThermoFisher; Table 5).

For isocyanates and acid anhydrides no suggested cut-off values exist. Testing sIgG against the three isocyanates and three acid anhydrides ranged from $<0.02$ to $8.6 \mathrm{mg}_{\mathrm{A}} / \mathrm{L}$ and the majority of values (649 out of 726 tests; $89 \%$ ) were $<2 \mathrm{mg}_{\mathrm{A}} / \mathrm{L}$ (Table 5 ).

Specific IgG values were not significantly influenced by smoking and sex (data not shown). Additionally, most of the sIgG values were unaffected by age with the exception of sIgG values against chicken feathers (e85) showing an increase of sIgG concentrations with increasing age $\left(\mathrm{r}_{\mathrm{s}}=0.2744, p=0.0023\right)$.

\section{Determination of total IgG- and HSA-specific IgG concentrations}

The total IgG concentration in most of the sera (98.4\%) was in the reference range (Table 7 ). In contrast to the specific IgG concentrations the raw data of total IgG concentration was normally distributed (Fig. 1) 

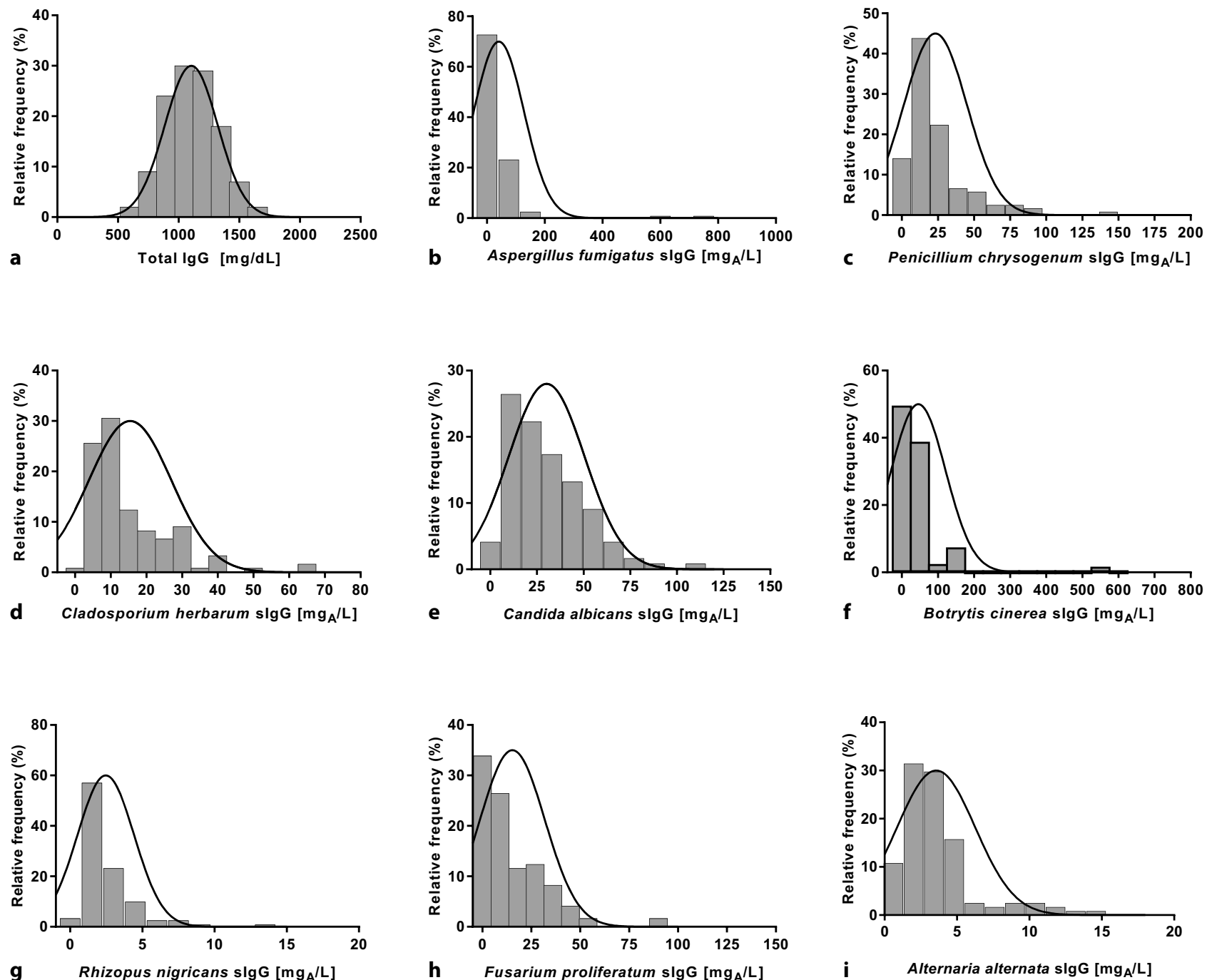

Fig. 1 Distribution of total $\lg G$ values and specific $\lg G$ values measured in reference sera of 121 healthy donors. a Total IgG, b Aspergillus fumigatus, c Penicillium chrysogenum, d Cla-

dosporium herbarum, e Candida albicans, f Botrytis cinerea, g Rhizopus nigricans, h Fusarium proliferatum, i Alternaria alternata

and affected by age (negatively correlated with age $\left.\mathrm{r}_{\mathrm{s}}=-0.2389, p=0.0083\right)$. Testing the unspecific binding to the ImmunoCAP (a spongy, hydrophilic activated cellulose carrier) by using HSA-ImmunoCAPs, in $92 \%$ of the sera the IgG concentrations against HSA were $<2 \mathrm{mg} / \mathrm{L}$ (Table 7). Based on the $97.5 \%$ quantile value measured against HSA, antigen-specific IgG values $<4 \mathrm{mg}_{\mathrm{A}} / \mathrm{L}$ will be classified as unspecific.

\section{Testing of reproducibility}

For further validation, sIgG determination was repeated twice with 10 different sera and 7 antigens and HSA covering the whole concentration range from $<0.02$ to $726 \mathrm{mg}_{\mathrm{A}} / \mathrm{L}$ (Table 8). Repeated measurements of sera with sIgG values $>2 \mathrm{mg}_{\mathrm{A}} / \mathrm{L}$ showed low $\mathrm{CV}$ values compared to sera with values $<2 \mathrm{mg}_{\mathrm{A}} / \mathrm{L}$. Especially for antigens like isocyanates and acid anhydrides with majority of values $<2 \mathrm{mg}_{\mathrm{A}} / \mathrm{L}$ the $\mathrm{CV}$ range was broad.

\section{Correlation of the specific lgG concentrations}

Figure 4 presents the correlations between all specific and total IgG values visualized with different colours and classified into different categories $\left(r_{s} \geq 0.75 ; r_{s}<0.75 \geq 0.5, r_{s}<0.5 \geq 0.25 ; r_{s}<0.25\right)$. Strong correlations $\left(r_{s} \geq 0.75\right)$ were noted between A. fumigatus (m3), P. chrysogenum (m1), C. herbarum (m2), and B. cinera $(\mathrm{m} 7)$. Similar strong correlations were found between M. racemosus ( $\mathrm{m} 4)$ and R. nigricans (m11), C. albicans (m5), and F. proliferatum (m9) and between T. viride (m15) and S. atra (Gm24). The thermophilic bacteria mixture (Gmx7) strongly correlated with T. vulgaris (Gm23) and slightly lower $\left(\mathrm{r}_{\mathrm{s}}=0.64\right)$ with $S$. rectivigula $(\mathrm{Gm} 22)$, both bacteria species are included in the mixture Gmx7. Remarkable and unexpected was the high correlation between Gm22 and the trimellitic acid (k86). All bird antigens significantly correlated with another $\left(\mathrm{r}_{\mathrm{s}} \geq 0.75\right.$ or $<0.75 \geq 0.5$ ), with the highest correlation between 


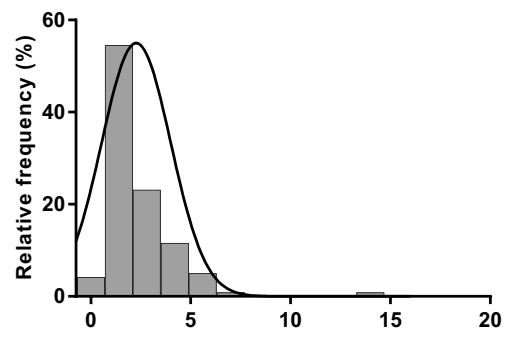

a Saccharopolyspora rectivirgula slgG $\left[\mathrm{mg}_{\mathrm{A}} / \mathrm{L}\right]$

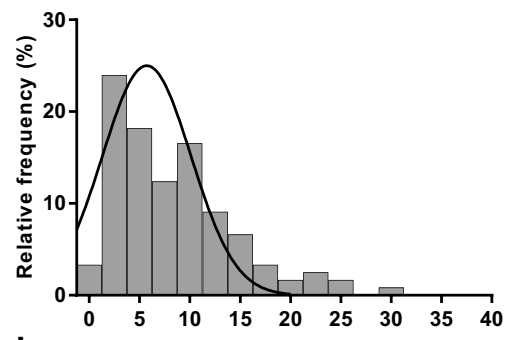

b Thermoactinomyces vulgaris slgG $\left[\mathrm{mg}_{\mathrm{A}} / \mathrm{L}\right]$
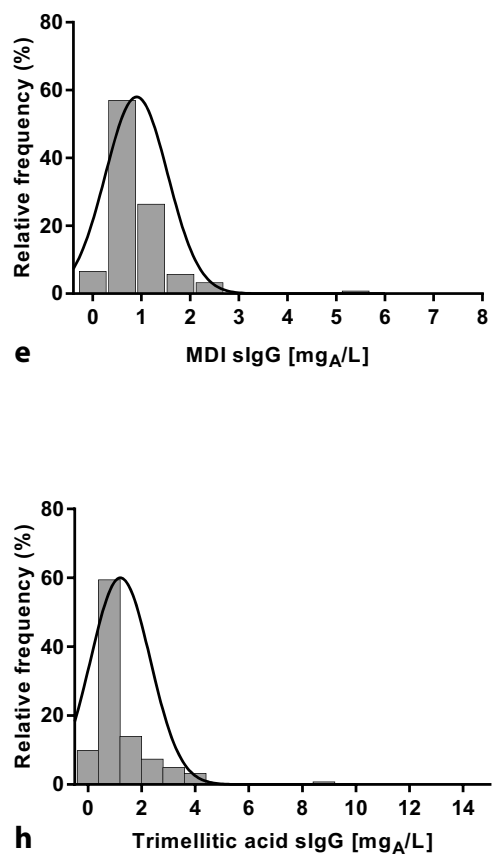

h
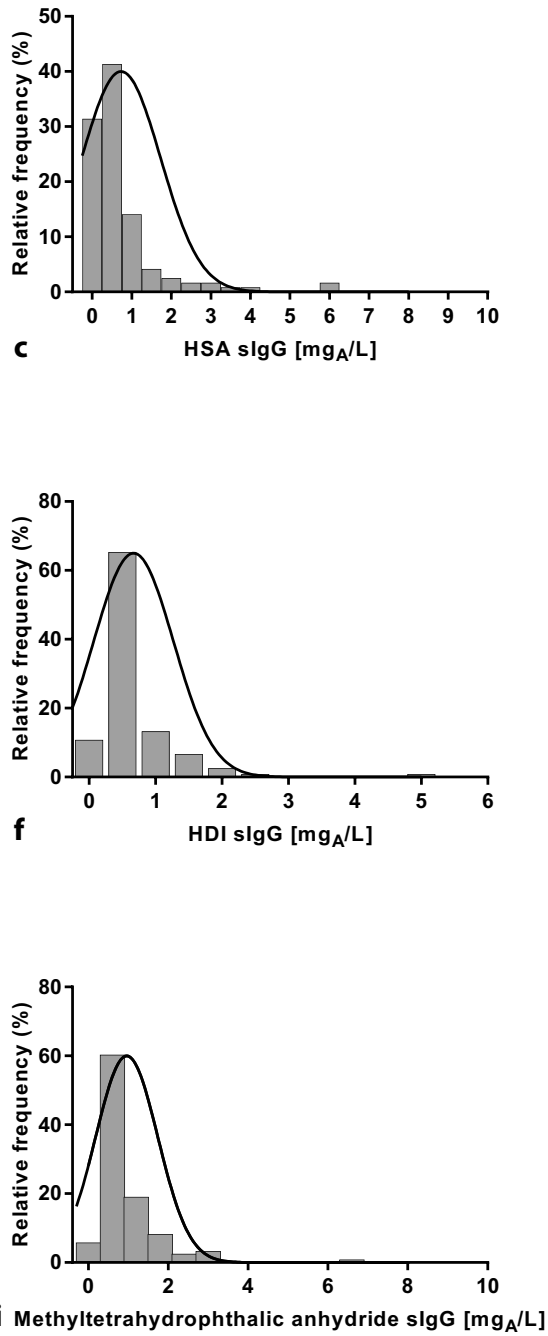

g

Phthalic acid slgG $\left[\mathrm{mg}_{\mathrm{A}} / \mathrm{L}\right]$

MDI (diphenylmethane diisocyanate), f Isocyanate HDI (hexamethylene diisosyanate), $\mathbf{g}$ Phthalic acid, $\mathbf{h}$ Trimellitic acid, i Methytetrahdydrophthalic anhydride ence sera of 121 healthy donors. a Saccharopolyspora rectivirgula, b Thermoactinomyces vulgaris, c Human Serum Albumin (HSA), d Isocyanate TDI (toluene diisocyanate), e Isocyanate

duck feathers (e86) and goose feathers (e70), pigeon antigens (Ge91), budgerigar antigens (Ge90), chicken feathers (e85) and pigeon serum proteins (Ge93), respectively. Additionally high correlations were noted between budgerigar antigens (Ge90) and canary feathers (e201), pigeon serum (Ge93) and goose feathers (e70), respectively. Furthermore high correlations were found between pigeon serum (Ge93) and canary feathers (e201), canary and goose feathers (e70), goose and chicken feathers (e85), and goose feathers and pigeon antigens (Ge91). Conspicuous were the high correlations between pigeon serum (Ge93) and all the chemicals (k75-k78, k79, k86, k211), and also between canary feathers (e201) and all chemicals. Highly positive correlations were noted between all three isocyanates $(\mathrm{k} 75, \mathrm{k} 76, \mathrm{k} 78)$ and two acid anhydrides (k86, k211). Especially the chemical-specific IgG values were highly positively correlated with HSA-specific IgG values. Especially in all these cases it should be noted that the majority of sIgG values were $<2 \mathrm{mg}_{\mathrm{A}} / \mathrm{L}$. Low $\left(\mathrm{r}_{\mathrm{s}}<0.5\right)$ correlations were noted between the antigen-specific IgG concentrations and the total IgG concentrations.

\section{Tool for the classification of specific IgG values from patients with a suspect of HP}

To use these sIgG values as reference values as one important criterion for the diagnosis of hypersensitivity pneumonitis we provide a calculator (available under https://www.ipa-dguv.de/ipa/publik/litinfos/ immunocap/index.jsp) to evaluate the measured antigen-specific IgG values. Only sIgG concentrations determined with the same system (ImmunoCAP, ThermoFisher Scientific) and with the same 32 antigens can be ranked in relation to the reference values with this calculator. 
Fig. 3 Distribution of specific IgG values measured in reference sera of 121 healthy donors. a Budgerigar serum proteins, feathers and droppings (Ge90), b Pigeon serum proteins, feathers and droppings (Ge 91), c Parrot serum proteins, feathers and droppings (Ge92), d Pigeon serum proteins (Ge93), e Goose feathers (e70), f Chicken feathers (e85), g Duck feathers (e86), h Canary feathers (e201)
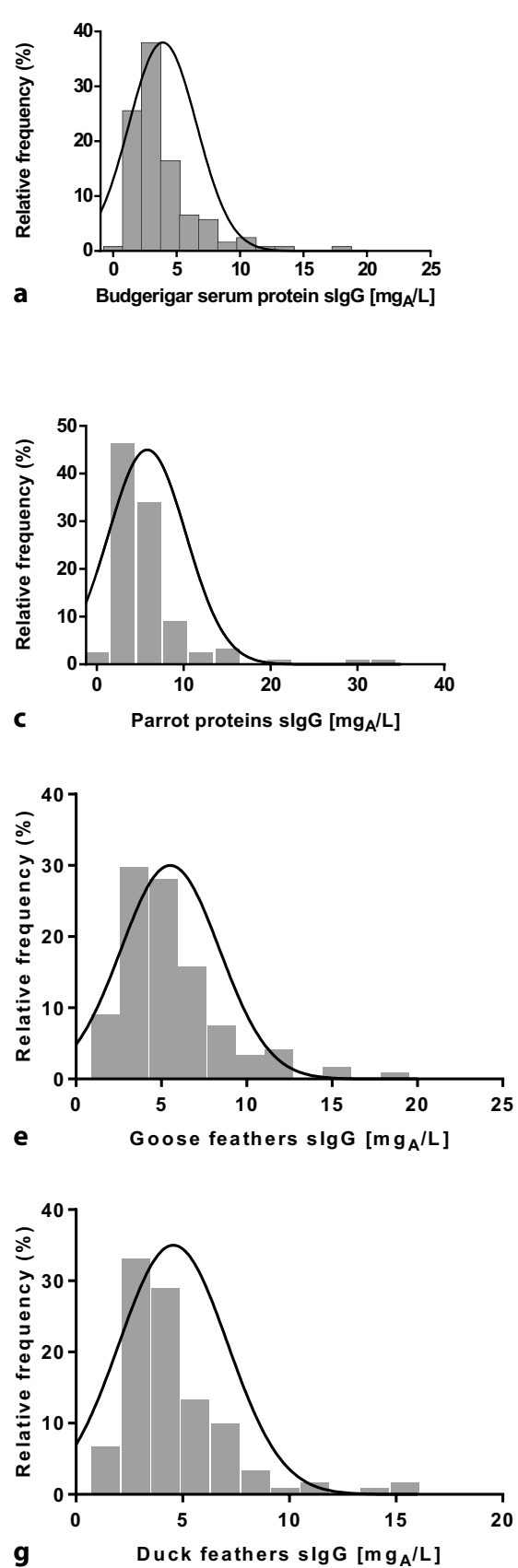
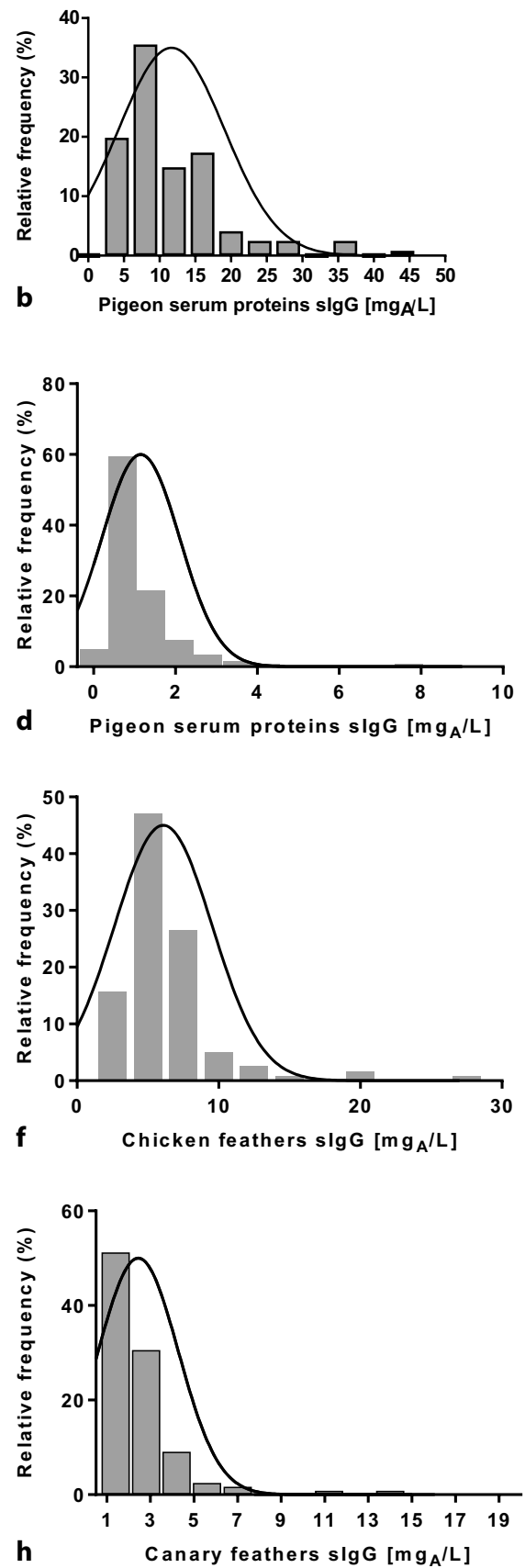

\section{Discussion}

We established antigen-specific IgG reference intervals for $32 \mathrm{HP}$ antigens using the frequently applied quantitative technique of ImmunoCAP FEIA. The number of sera $(n=121)$ from healthy volunteers without any clinical signs of HP and without obvious exposure to potential HP antigens was suitable to establish reference ranges. Already in the past several studies were published dealing with the objective to establish cut-off or reference values to assess antigen-specific IgG concentrations measured within the diagnosis of HP [7-11]. In most of the studies the authors focused on a special group of antigens (e.g. avian antigens $[9,12,13])$ or used special in-house methods (e.g. ELISA technique [14]), and/or only a limited number of sera from control subjects were available [8]. Furthermore, the criteria to define reference and cut-off values differed between the studies (e.g. as mean plus 3 standard deviations or as $95 \%$ confidence interval or $97.5 \%$ quantile). Therefore an advantage of our study is that we used a standardized quantification system, and determined the antigenspecific IgG concentrations in 121 representative sera of apparently healthy donors with all antigens that were commercially available at the time of the investigation. Our study group consists of $56 \%$ women and $44 \%$ men, aged between 21 and 83 years, $62 \%$ of them 
Table 7 Determination of total IgG and HSA-specific IgG in the 121 sera of the study group

\begin{tabular}{|c|c|c|c|c|c|c|c|}
\hline & Range (min-max) & Values $<2[n]$ & Median & 75\% Quantile & 95\% Quantile & $97.5 \%$ Quantile & Reference range \\
\hline Total lgG [mg/L] & $6160-17,010$ & l & 10,880 & 12,620 & 14,890 & 15,630 & $7000-16,000$ \\
\hline HSA (Ro401) [mg/ $/ \mathrm{L}]$ & $<0.02-6.2$ & 111 & 0.4 & 0.8 & 2.7 & 4.0 & l \\
\hline
\end{tabular}

Table 8 Testing of repro-
ducibility

Antigen
$\begin{aligned} & \text { A. fumigatus } \\ & \text { m3 }\end{aligned}$
A. pullulans
m12
S. rectivirgula
Gm22
Budgerigar antigens
Ge90
Goose feathers
e70
Isocyanate-MDI
k76
Methyltetrahydrophthalic
anhydride
k211
HSA
R0401

\begin{tabular}{|c|c|c|c|c|}
\hline $\begin{array}{l}\text { Number of } \\
\text { sera }[n]\end{array}$ & $\begin{array}{l}\text { slgG-range of the sera } \\
(n=10) \text { used for validation } \\
{\left[\mathrm{mg}_{\mathrm{A}} / \mathrm{L}\right]}\end{array}$ & $\begin{array}{l}\text { Number of } \\
\text { slgG }<2 \mathrm{mg}_{A} / \mathrm{L}\end{array}$ & $\begin{array}{l}\text { CV [\%] } \\
{[\text { mean } \pm \text { SD] }}\end{array}$ & $\begin{array}{l}\text { CV [\%] } \\
\text { [range] }\end{array}$ \\
\hline 10 & $4.1-726.1$ & 0 & $9.9 \pm 12.6$ & $0-39.6$ \\
\hline 10 & $0.2-26.4$ & 2 & $27.3 \pm 31.1$ & $1.6-109.3$ \\
\hline 10 & $0.4-14.2$ & 3 & $25.2 \pm 24.2$ & $5.1-69.8$ \\
\hline 11 & $0.7-18.0$ & 4 & $21.0 \pm 13.7$ & $3.2-45.5$ \\
\hline 10 & $1.6-18.8$ & 2 & $27.6 \pm 19.2$ & $2.6-49.1$ \\
\hline 10 & $0.3-5.5$ & 6 & $75.1 \pm 59.2$ & $1.4-135.5$ \\
\hline 10 & $<0.02-6.3$ & 7 & $66.1 \pm 58.5$ & $0-136.9$ \\
\hline 10 & $<0.02-6.2$ & 4 & $70.9 \pm 62.7$ & $0-140.0$ \\
\hline
\end{tabular}

and $8.81 \mathrm{mg}_{\mathrm{A}} / \mathrm{L}$, respectively) to differentiate patients with feather duvet lung or bird fancier's lung from healthy subjects [8] are higher than $93.2 \%$ or $93.8 \%$ of our reference sera, respectively.

In contrast to the study of Makkonen et al. [16] who reported higher specific IgG titers for several mould-antigens in healthy women $(n=18)$ compared to healthy men $(n=13)$ and suggested that separate reference intervals may be necessary for men and women, in our study group (including sera from 68 women and 53 men) no significant sex differences in the specific IgG response values to any of the tested antigens could be identified. Therefore no different reference intervals for men and women are required. Additionally no significant effect of smoking was measured in our study group. Only with one exception (sIgG values against chicken feathers [e85]) all sIgG values were unaffected by age. It should be taken into account that for adolescents or children (younger than 21 years) different reference intervals may be necessary.

All tested sera revealed sIgG antibodies $>2.0 \mathrm{mg}_{\mathrm{A}} / \mathrm{L}$ against at least one antigen, but the levels of IgG antibodies against the different antigens varied considerably. Low sIgG concentrations for example were found against the tested chemicals (diisocyanates and acid anhydrides); the highest levels were detected against fungal antigens, especially to Aspergillus fumigatus and Botrytis cinerea. Although diisocyanates and acid anhydrides are typical workplace-related substances and not ubiquitously disturbed in the environment, 


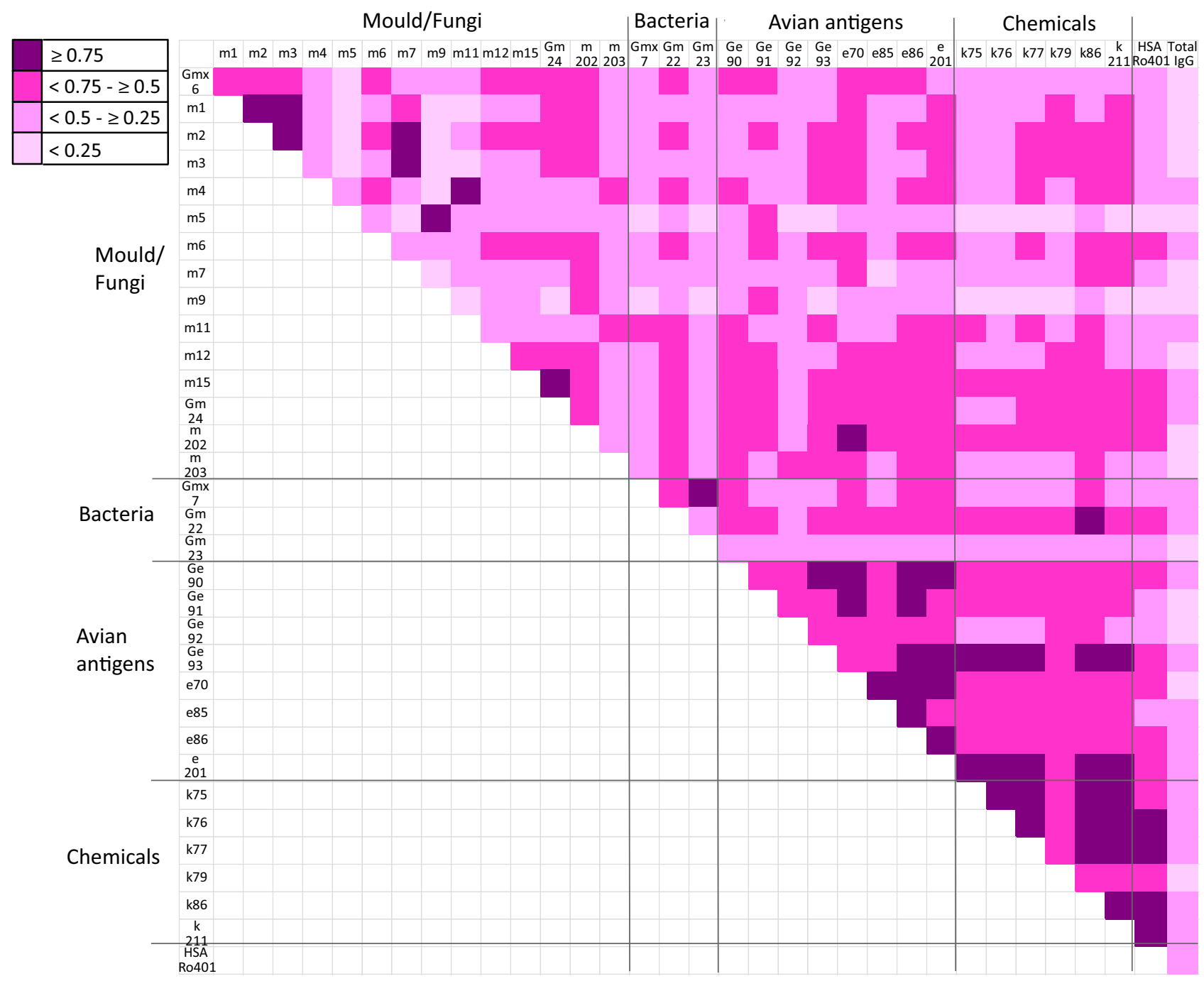

Fig. 4 Spearman correlation between the antigen-specific IgG titers, total IgG and HSA-slgG. Visualized with different colours and classified into different categories ( $r s>0.75 ; \mathrm{rs}<0.75>0.5, \mathrm{rs}<0.5>0.25 ; \mathrm{rs}<0.25$ )

several studies demonstrated IgG binding to HDIHSA and TDI-HSA in individuals without known exposure to isocyanates $[17,18]$. Between $75 \%$ and $93 \%$ of all reference sera revealed sIgG concentrations against the three tested diisocyanates and the three acid anhydrides below the limit of quantification $\left(<2.0 \mathrm{mg}_{\mathrm{A}} / \mathrm{L}\right)$. Therefore the assessed $97.5 \%$ quantile was low $\left(<6 \mathrm{mg}_{\mathrm{A}} / \mathrm{L}\right)$ and in the range of unspecific IgG binding measured with the HSA-ImmunoCAP (97.5\% quantile $\left.4 \mathrm{mg}_{\mathrm{A}} / \mathrm{L}\right)$. Due to the high correlation between the sIgG values against the chemicals and the HSA, we recommend to check the specificity in case of suspected chemically induced HP using an additional test with HSA-ImmunoCAP. This is especially recommended when all chemicals tested have elevated SIgG values. Additionally, confirmed by the results published by Hemmer et al. [19] for non-specific IgE background-binding in sera with high levels of anti-CCD IgE antibodies we recommended for sera with high sIgG titers against many different antigens to identify non-specific background-binding by test- ing for example with HSA-ImmunoCAP or possibly with non-allergenic maltose-binding protein- (MBP-) ImmunoCAP.

In contrast to the low chemical-specific IgG values the sIgG responses against the 14 fungi and the mould mixture were heterogeneous and covered a wide measurement range. The occurrence of specific IgG titers in healthy controls suggests that all people were exposed to fungus-derived antigens to some extent. In contrast to the chemicals tested in this study, a large number of fungi are ubiquitous in our environment, not limited to for example workplaces, and in these cases exposure cannot be avoided. Wide ranges of sIgG responses were determined against $P$. chrysogenum (1.8-143.0 $\left.\mathrm{mg}_{\mathrm{A}} / \mathrm{L}\right)$, Botrytis cinerea $(0.3-572$ $\mathrm{mg}_{\mathrm{A}} / \mathrm{L}$ ) and especially against $A$. fumigatus (2.6-726.0 $\mathrm{mg}_{\mathrm{A}} / \mathrm{L}$ ). Although principally the same sIgG detection method (UniCAP) was used in former studies [7, 10, 16], specific IgG values especially against $A$. fumigatus obtained from healthy controls were different. One explanation might be that sera were collected from 
different parts of Europe (Finland, Austria, Belgium versus Germany), and fewer individuals were tested than in our study, but also the variability of the antigen coupled to the ImmunoCAP in the period of 15 years might play a role.

Due to the different ranges of the IgG concentrations, which were determined for the individual fungi antigens, the exclusive application of the mould mixture as screening test does not seem meaningful in the IgG diagnostics because of possible underestimation of IgG response to individual fungal antigens.

Additionally strong correlations between some fungal antigens (P. chrysogenum, C. herbarum, A. fumigatus and B. cinera) or between the bird-related antigens indicate the possibility of cross-reactivity between these species. These findings are consistent with previous results for some fungal antigens [16] and for bird-related antigens [8].

In some cases unexpected high correlations were observed (e.g. between Saccharopolyspora rectivirgula [Gm22] and the trimellitic acid [k86] or between goose feather [e70] and Acremonium kiliense [m202]). In these cases cross-reactivity based on similar epitopes on the antigens seems to be unlikely. The sIgG concentrations are relatively low and therefore a correlation dependent on unspecific binding to the cellulose matrix and random effects might be responsible.

In conclusion, our study offers antigen-specific IgG reference intervals for 32 important HP antigens using the frequently applied quantitative technique of ImmunoCAP.

For further validation, it is desirable to compare the findings of this study with sIgG values of definitely diagnosed HP patients. Realistically, however, this will be difficult to achieve for many HP subtypes due to the small number of cases. Nevertheless we suggest considering the determined sIgG values for a better classification of SIgG concentrations in the scope of HP diagnosis. To facilitate the use of these values, we have created the online available calculator which ranks the entered values in relation to the reference quantiles. Of course only values obtained with the same method (ImmunoCAP) can be evaluated. Measurements with the same reference collective and a different IgG quantification method will be published soon.

Acknowledgements The authors are thankful for the support of ThermoFisher Scientific, who had provided ImmunoCAPs/ reagents free of charge. Neither the design of the study nor the evaluation of the data were influenced by ThermoFisher Scientific. We thank C. Bittner, Hamburg, for help in collecting the samples, B. Kendzia, Bochum, for statistical support and U. Meurer, Bochum, for skilful technical assistance.

\section{Compliance with ethical guidelines}

Conflict of Interest M. Raulf received honorarium for lectures on scientific meetings from HAL Allergy, ThermoFisher Scientific and Astellas. D. Koschel received honorarium for lectures on scientific meetings from Boehringer Ingelheim and Roche. M. Joest received lecture fees for a webinar from ThermoFisher Scientific Phadia. I. Sander, F. Hoffmeyer, D. Nowak, U. Ochmann, A. Preisser, J. Schreiber and J. Sennekamp declare that they have no competing interests.

Ethical approval The study design and the protocol were reviewed and approved by the ethical committee of the Technische Universität Dresden (EK 195052014) in accordance with the Declaration of Helsinki and ethical approval was obtained from the local ethic committee of each centre.

Open Access This article is distributed under the terms of the Creative Commons Attribution 4.0 International License (http://creativecommons.org/licenses/by/4.0/), which permits unrestricted use, distribution, and reproduction in any medium, provided you give appropriate credit to the original author(s) and the source, provide a link to the Creative Commons license, and indicate if changes were made.

\section{References}

1. Riario Sforza GG, Marinou A. Hypersensitivity pneumonitis: a complex lung disease. Clin Mol Allergy. 2017;15:6. https://doi.org/10.1186/s12948-017-0062-7.

2. Nogueira R, Melo N, Novais E, Bastos H, Martins N, Delgado L, et al. Hypersensitivity pneumonitis: antigen diversity and disease implications. Pulmonol. 2018; https://doi.org/ 10.1016/j.pulmoe.2018.07.003.

3. Cormier Y. Hypersensitivity pneumonitis (extrinsic allergic alveolitis): a Canadian historical perspective. Can RespiratoryJ.2014;21:277-8.

4. Girard M, Cormier Y. Hypersensitivity pneumonitis. Curr Opin Allergy Clin Immunol. 2010;10:99-103.

5. Sennekamp J, Müller-Wening D, Amthor M, Baur X, Bergmann K-C, Costabel U, et al. Empfehlungen zur Diagnostik der exogen-allergischen Alveolitis. Arbeitgemeinschaft Exogen-Allergische Alveolitis der Deutschen Gesellschaft für Pneumologie und Beatmungsmedizin e. V. (DGP) und der Deutschen Gesellschaft für Allergologie und Klinische Immunologie (DGAKI). Pneumologie. 2007;61:52-6. Guidelines for diagnosing extrinsic allergic alveolitis (hypersensitivity pneumonitis) (German ExtrinsicAllergic Alveolitis Study Group).

6. QuirceS, Vandenplas O, CampoP,CruzMJ, deBlayF, Koschel D, et al. Occupational hypersensitivity pneumonitis. An EAACI position paper. Arerugi. 2016;71:765-79.

7. Kränke B, Woltsche M, Woltsche-Kahr I, Aberer W. IgGAntikörper gegen „EAA-spezifische Umweltantigene“ Die Problematik der Normalwertdefinition. Allergologie. 2001;24:145-54.

8. Koschel D, Lutzkendorf L, Wiedemann B, Hoffken G. Antigen-specific IgG antibodies in feather duvet lung. Eur J Clin Invest. 2010;40:797-802.

9. Lopata AL, Schinkel M, Potter PC, Jeebhay MF, Hashemi C, Johansson SG, et al. Qualitative and quantitative evaluation of bird-specific IgG antibodies. Int Arch Allergy Immunol. 2004;134:173-8.

10. van Hoeyveld E, Dupont L, Bossuyt X. Quantification of IgG antibodies to Aspergillus fumigatus and pigeon antigens by ImmunoCAP technology:an alternative to the precipitation technique? Clin Chem. 2006;52:1785-93.

11. Sennekamp J, Lehmann E, Joest M. Berufsbedingte exogenallergische Alveolitis. Arbeitsmed Sozialmed Umweltmed. 2015;50:38-52.

12. McSharry C, Dye GM, Ismail T, Anderson K, Spiers EM, Boyd G. Quantifying serum antibody in bird fanciers' hypersensi- 
tivity pneumonitis. Bmc Pulm Med. 2006;6:16. http://www. biomedcentral.com/1471-2466/6/16.

13. Bañales JL, Vázquez L, Mendoza F, Baltazares M, Raymond $\mathrm{Y}$, Nava A, et al. On the correct determination of reference values for serum antibodies against pigeon serum antigen using a group of healthy blood donors. Arch Med Res. 1997;28:289-91.

14. Rodrigo MJ, Benavent MI, Cruz MJ, Rosell M, Murio C, Pascual C, Morell F. Detection of specific antibodies to pigeon serum and bloom antigens by enzyme linked immunosorbent assay in pigeon breeder's disease. Occup Environ Med. 2000;57:159-64.

15. Sennekamp H-J. Extrinsic allergic alveolitis, Hypersensitivity pneumonitis. Munich, Orlando: Dustri-Verl. Feistle; 2004. ISBN 3-87185-309-7.

16. Makkonen K, Viitala KI, Parkkila S, Niemelä O. Serum IgG and IgE antibodies against mold-derived antigens in patients with symptoms of hypersensitivity. Clin Chim Acta. 2001;305:89-98.

17. Bernstein DI, Ott MG, Woolhiser M, Lummus Z, Graham C. Evaluation of antibody binding to diisocyanate protein conjugates in a general population. Ann Allergy Asthma Immunol. 2006;97:357-64.

18. Pronk A, Preller L, Raulf-Heimsoth M, Jonkers ICL, Lammers J-W, Wouters IM, et al. Respiratory symptoms, sensitization, and exposure response relationships in spray painters exposed to isocyanates. Am J Respir Crit Care Med. 2007;176:1090-7.

19. Hemmer W, Altmann F, Holzweber F, Gruber C, Wantke F, Wohrl S. ImmunoCAP cellulose displays cross-reactive carbohydrate determinant (CCD) epitopes and can cause false-positive test results in patients with high anti-CCD IgE antibody levels. JAllergy Clin Immunol. 2018;141:372-81. 